DOI: https://doi.org/10.31933/dijms.v2i4

Received: 26 January 2021, Revised: 7 March 2021, Publish: 15 April 2021

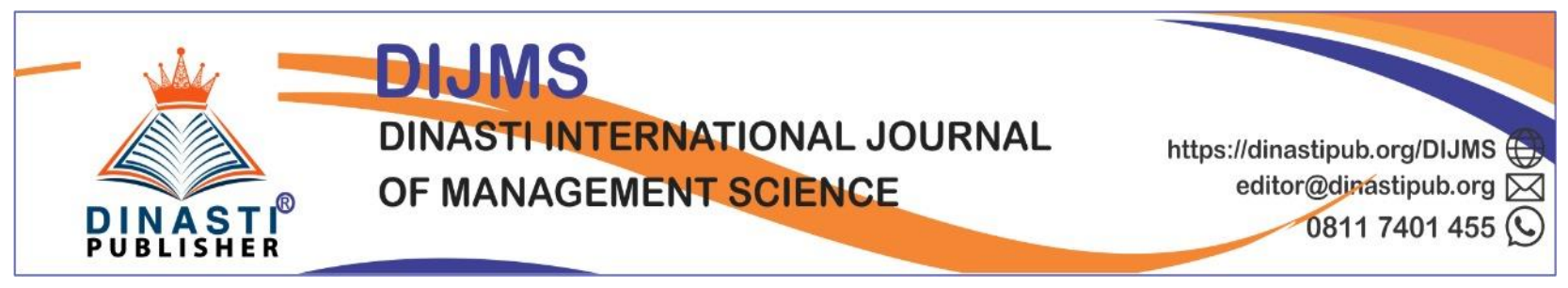

\title{
MEDIATION ACTS FROM EMPLOYEE ENGAGEMENT WHICH AFFECTS THE EMPLOYEE COMPETENCIES AND INNOVATIVE WORK BEHAVIOUR ON EMPLOYEE PERFORMANCE AT PT TETRA PAK INDONESIA
}

\author{
Andika Budiprasetia ${ }^{1}$, Singmin Johanes Lo ${ }^{2}$ \\ 1) Universitas Mercu Buana, Jakarta, Indonesia, andika.bp28@ gmail.com \\ ${ }^{2)}$ Universitas Mercu Buana, Jakarta, Indonesia, singmin.johanes@mercubuana.ac.id
}

Corresponding Author: Andika Budiprasetia

\begin{abstract}
These research was intend to discovered the mediate acts from employee engagement in influencing the affect of employee competence and innovative behaviour on Employees' performance at PT Tetra Pak Indonesia. These research population here used saturated sample from all service engineer employees, with a total sample of 76 service engineers. The data analysis method used Structural Equation Model-Partial Least Square (SEM PLS). The research outcomes showed that innovative behaviour did not have an significant affect towards Employee performance. Competence had an positive impact in increasing the employee engagement and also this employee engagement could be able to motivate the Innovative behaviour and Employee performance.
\end{abstract}

Keywords: Competence, innovative behaviour, employee engagement and employee performance.

\section{INTRODUCTION}

Innovation is one thing that always need to be done in order to develop a better organization. The success in developing an organization was influenced by several factors, one of that is an human resources. The growth of business and competition in the business world has increase rapidly so it would requires An excellent human resources. Many factors that could affect the employee performance improvement, such as : leadership, work discipline, work environment and innovative behaviour from the employees. Innovative behaviour could be defined as the proposal and application of new ideas, processes, practices and policies which aimed to increase an organizational effectiveness, business success and long-term sustainability (Anderson et al., 2014; Janssen, 2000).

One thing that could be a key to success is what is called employee engagement. Employee engagement is a situation where the employee has a strong commitment to their job, the company's goals and its company value. Another factor that has impact on employee performance is training and development that carried out in order to enhance the ability and 
knowledge of employee so then with increasing person's competence particularly when facing new conditions. This related to careers and it is hope that it could be as an effort to overcome the expiration of the human resources in the organization.

PT Tetra Pak Indonesia is a multinational company which offers an integrated solutions for food and beverage processed and packaging. PT. Tetra Pak services cover every aspect of food production, from daily routines to business scales. Tetra Pak's dedicated service solutions not only improve the performance, optimize costs and ensure food safety throughout the operating cycle on each production line which requiring an optimal employee performance. To determine the variables that need to be examined could be used an initial interview with two key persons who understand about what is it happening in the research place, in this case probably the FSO (Field Service Organization) Area Manager and HR Country Manager, to reveal which variables that need to be focused in this research.

This because the company are conducts an EE (Empolyee Engagement) survey every two years for all employees. It could be seen through Figure 1that there are several results which have been decreased compared to 2017, such as quality, customer focus, communication (competence), innovation and engagement well being. So that these three variables are the variables that need to be analyzed further and improved. Those are competence, innovative behaviour and employee engagement which has an impact towards employee performance.

\begin{tabular}{|c|c|c|}
\hline & Total Favorable Score & $\begin{array}{c}\text { Tetra Pak } \\
\text { Overall 2017 } \\
(19,926)\end{array}$ \\
\hline Engagement \& Well-Being & 82 & -1 \\
\hline Career Development & 71 & 0 \\
\hline Quality and Efficiency & 77 & $-3^{*}$ \\
\hline Customer Focus & 76 & $-5^{\star}$ \\
\hline Communication & 65 & $-4^{\star}$ \\
\hline Performance Management & 82 & -1 \\
\hline Change & 60 & $-2^{\star}$ \\
\hline Collaboration & 76 & 0 \\
\hline Environmental Responsibility & 91 & $-2^{\star}$ \\
\hline Innovation & 65 & $-3^{*}$ \\
\hline Reward and Recognition & 52 & $1^{*}$ \\
\hline Diversity and Inclusion & 78 & $\mathrm{n} / \mathrm{a}$ \\
\hline Leadership index & 76 & 0 \\
\hline Inclusion index & 74 & 0 \\
\hline
\end{tabular}

Figure 1. Tetra Pak 2019 The Towers Watson Survey

Several priors research shown that innovation behaviour had a positive and significant impact on employee engagement (Dibrell \& Craig, 2013; Sagung \& Dewi, 2018; Shanker \& Bhanugopan, 2017; Sujarwo \& Wahjono, 2017; Tajeddini \& Martin, 2019). Competence had a positive impact on employee performance (Ataunur \& Ariyanto, 2015; Shaputra \& Hendriani, 2015). Competence had a positive impact on employee engagement (Dayona \& Rinawati, 2016). Competence did not affect the level of employee involvement (Claret \& Harry, 2014). Employee engagement had a direct positive affect on employee performance (Bedarkar \& Deepika, 2014) The mediating role of employee engagement shows significant results on innovative behaviour (Ardy L Prasetyo, 2018). Employee engagement mediation has affects the employee performance (Fajriah Nailul, 2016). Training and development have a significant 
affect on employee performance with help of employee engagement as mediation (Parura AW, 2018).

According to this phenomenon, pre-survey and research gap, the authors wanted to investigate more about the influence of competence, innovative behaviour and employee engagement on employee performance and intend to see the role of employee engagement as an mediating variable in influencing the competence and innovative behaviour in an effort to improve the employee performance at PT Tetra Pak Indonesia.

\section{LITERATURE REVIEW \\ Employee performance}

Michael Armstrong (2018: 8) defines the performance as an concept with multiple dimensions and its measurement depends on the number of different factors. The Performance could be explained as the quality and quantity of work achieved by an employee in carrying out their duties according to its responsibilities (Mangkunegara, 2016). According to Mangkunegara (2014: 67)the employee performance could be measured through 5 dimensions, namely: quality of work, quantity of work, responsibility, teamwork, and initiative.

\section{Innovative Behaviour}

Based on the research from De Jong, et al (2008) which stated thar innovative behaviour is an individual behaviour which aims to reach the introduction steps or try to introduce new and useful ideas, processes, products or procedures in work, groups or organizations. Roger and Roger (1976) said that this innovation would have limitations as notions or ideas, practice and in the form of tools or objects which considered new by people. Meanwhile, Robbins \& Judge (2014) argues that innovation is a renewal, new invention, in the form of ideas, methods, tools, product results or others. Janssen (2000) has describes those three dimensions to estimate the innovative behaviour in the workplace such as : creating new ideas, sharing the ideas and realizing the ideas.

\section{Employee Engagement}

Kahn (2005) described that employee engagement as personal engagement that used themselves as members of organization to perform their job roles and people who were employed would express themselves physically, cognitively and emotionally during their performance. These engaged organization has authentic strength and values with clear evidence of trust and justice based on mutual respect, whereas both employer and employee have a promise and commitment which is understood and fulfilled (McLeod, 2009: 5). According to Schaufeli \& Bakker (2003: 25) the employee engagement consists of three elements such as vigor, dedication and absorption.

\section{Competence}

Francoise and Winterton (2005) were explained that competence is common as ability, which is the concept of bringing together knowledge and skills from various important elements. Furthermore, according to Lasmahadi (2002) competence could be defined as the personal aspects of a worker which enable them to achieve an excellent performance. The dimensions of competence which uttered by Spencer \& Spencer (1993) consist of: motive, character, self-concept, knowledge, and skills. 


\section{Theoretical Framework and Hypothesis}

The theoretical framework was made as basic for answering the research objectives, such as in order to scientifically prove that: 1) The impact of competence on employee performance, 2) The impact of competence on employee engagement, 3) The impact of innovative behaviour on employee performance 4) The impact of innovative behaviour on employees engagement, 5) the impact of employee engagement on the performance 6) the role of employee engagement as mediating variable in influencing the competence on employee performance 7) the role of employee engagement in mediating the influence of innovative behaviour on employee performance.

\section{RESEARCH METHOD}

The research method used in this research was associative causal research to revealed the causal relations between the research variables. Independent variables in this research were competence, innovative behaviour, the dependent variable was employee performance, and the mediating variable was employee engagement. The estimation scale in this research was a Likert scale. The research population were employees at PT Tetra Pak Indonesia, with a total population of 76 engineers. The sampling determination used was saturated sample by taking all members of population as respondents in other word research sample would be 76 engineers. The data analysis method used Structural Equation Model-Partial Least Square (SEM PLS) to examine the hypothesis.

\section{RESULT AND DISCUSSION Respondent Characteristics}

According to the characteristics from 76 respondents who were all engineers of PT Tetra Pak Indonesia which the majority are male (96.1\%)aged between 31-40 years old (47.4\%) have a bachelor's degree (72.4\%) Length of work $<5$ years $(55.3 \%)$ and work in the service section field (68.4). This illustrates that the majority of PT Tetra Pak Indonesia's engineers were men who know has lots of knowledge / visions to provide the best service to customers in order to achieve their work targets.

\section{Outer Model Measurement}

According to the convergent validity test, it is found that all indicators have a loading factor value of > 0.5, except for the indicators of X205, X207, X208, M02 and Y04, then these indicators were removed from the model and a second test was carried out. On the second test, all research indicators have a loading factor value range between $0.524-0.873$ so all of them were declared valid. 


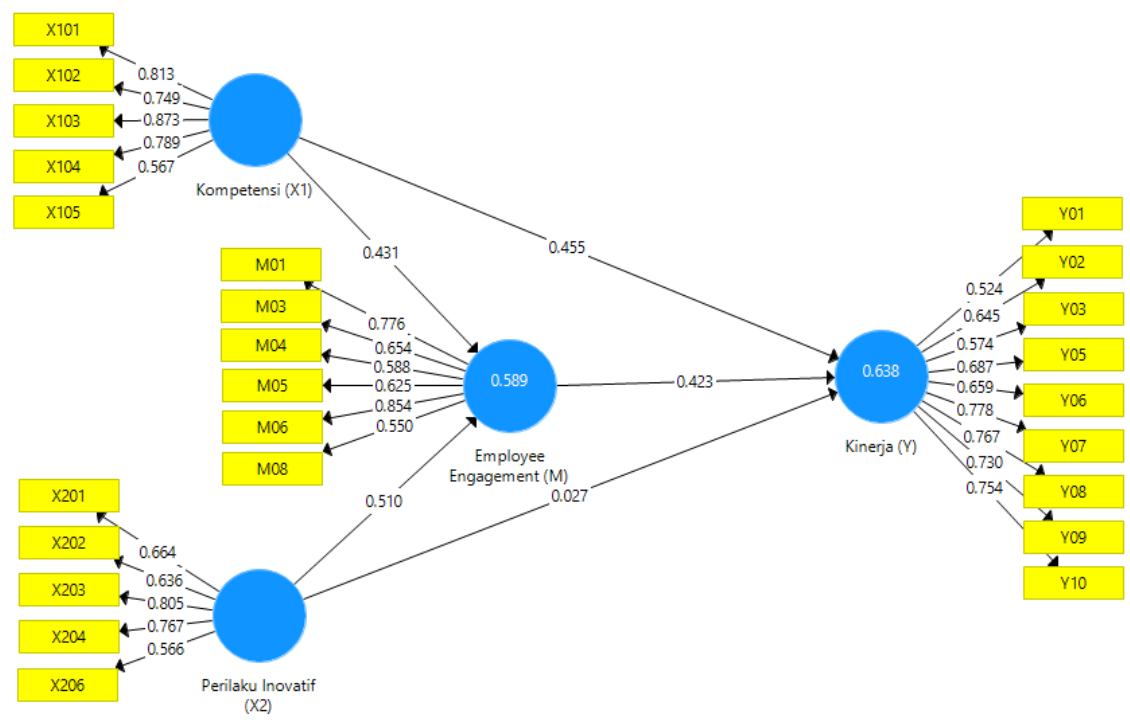

Figure21. PLS Algoritm (Modification)

According to the reliability test, it is found if all research variables were declared reliable, because they had Cronbach's alpha values and composite reliability between $0.728-0.887$ and all values are $>0.7$.

\section{$\mathbf{R}^{2}$, Stone-Geisser $\left(Q^{2}\right)$ and GoF Test}

The $\mathrm{R}^{2}$ values for employee engagement and employee performance were 0.589 and 0.638 . Then, the value of $\mathrm{Q}^{2}>0$, so this model could be said has a good predictive relevance.

\section{Hypothesis Test}

The results from the hypothesis test from this research could be seen through this table below.

Table 1. Hypothesis Test Results

\begin{tabular}{|l|c|c|c|c|c|}
\hline \multicolumn{1}{|c|}{ Relations Between Constructs } & $\begin{array}{c}\text { Original } \\
\text { Sampel }\end{array}$ & $\begin{array}{c}\text { Sampel } \\
\text { Mean }\end{array}$ & $\begin{array}{c}\text { Std. } \\
\text { Dev }\end{array}$ & $\begin{array}{c}\text { T } \\
\text { Statistics }\end{array}$ & $\begin{array}{c}\mathrm{p} \\
\text { Values }\end{array}$ \\
\hline Competance > Employee Performance & 0,455 & 0,469 & 0,085 & 5,334 & 0 \\
\hline Competance > Employee Engagement & 0,431 & 0,453 & 0,097 & 4,428 & 0 \\
\hline Innovative Behaviour -> Employee Performance & 0,027 & 0,031 & 0,089 & 0,299 & 0,765 \\
\hline Innovative Behaviour -> Employee Engagement & 0,510 & 0,492 & 0,119 & 4,277 & 0 \\
\hline $\begin{array}{l}\text { Employee Engagement > Employee } \\
\text { Performance }\end{array}$ & 0,423 & 0,405 & 0,108 & 3,927 & 0 \\
\hline $\begin{array}{l}\text { Competence > Employee Engagement > } \\
\text { Employee Performance }\end{array}$ & 0,182 & 0,182 & 0,058 & 3,157 & 0,002 \\
\hline $\begin{array}{l}\text { Innovative Behaviour > Employee } \\
\text { Engangement > Employee Performance }\end{array}$ & 0,215 & 0,202 & 0,078 & 2,773 & 0,006 \\
\hline
\end{tabular}

According to the hypothesis test result which mentioned above, it could be concluded that competence and employee engagement have a positive and significant affect on employee performance, while innovative behaviour has no affect towards employee performance. 
Competence and innovative behaviour have a positive and significant affect on employee engagement. The employee engagement could be use as mediate variable in effecting the competence and innovative behaviour on employee performance.

\section{Discussion}

According to the hypothesis test on this research, it shows that competence has a positive affect on employee performance. According to Francoise and Winterton (2010), they were defined the competence as common as ability, namely the concept which combined both knowledge and skills from various important elements, where the competence will direct into behavior and while behavior would produce performance. According to these observation it tells that a high level of competence would improve the performance. This research was in line with research by Ataunur and Ariyanto (2015) who found that the competence had a positive affect on employee performance.

According to the hypothesis test in this research, it shows that competency had a positive affect on employee engagement. Employee engagement is an important issue in achieving organizational effectiveness, whereas the employee engagement is related to employee performance (Wardani \& Anwar, 2019). According to these observation which stated that a high level of competence will affect the employee engagement. This research was in line with research by Herawaty \& Cahya (2020) who found that competence had a positive affect on employee engagement.

According to the hypothesis test in this research, the result shows that innovative behaviour has no affect on employee performance. Based on these explanations from several figures, such as De Jong (2008), Roger (2009) and Robbins (2006) it could be interpreted that innovative work behaviour is the action of individuals who are capable to create new ideas, products, problem solving and technologies. The most important thing from innovative work behaviour is how the employees could searching for creative ideas then seeking the support and end with the application of work practices so the targets performance could be achieved. According to these observation which stated that high innovative behaviour do not necessarily involved to produced an excellent performance, without support from the colleagues, superiors and organization, those sparked idea might not well conveyed. This opposites with the research from Tajeddini \& Martin (2019).

According to the hypothesis test in this research shows that innovative behaviour has a positive affect on employee engagement. In contrast to the correlations between the research results from innovative behaviour and performance, innovative behavior has a positive affect on employee engagement, because innovative behaviour is a form of introduction and implemented of new ideas, processes, products and procedures to groups or companies or organizations which directly related to employee engagement. This research was in line with research from Subchan et al (2017) who found that innovative behaviour has a positive affect on employee engagement.

According to the hypothesis test in this research, it shows that employee engagement has a positive affect on employee performance. In order word could be said that the increasing employee engagement would improve the employee performance aswell, because the engagement will encourage the employees to deliver the better performance. Employees who are engaged in their work often would produce better results on the individual, team and organizational levels (Bakker \& Demerouti, 2014). This research was in line with research by 
Agnes et al (2017) who found that innovative behaviour has a positive affect on employee performance.

According to the hypothesis test in this research, it shows that the competence and innovative behaviour have a positive affect through employee engagement as a mediate variable on employee performance. Competence and innovative behaviour have a positive and significant affect on employee performance directly or through mediation from employee engagement as mediatior. Based on the observation results, it could be indicated that employee engagement could mediates the competence and innovative behaviour on employee performance.

\section{CONCLUSION AND SUGGESTION Conclusion}

From these research result and discussion of the data analysis which carried out by the author, those conclusions that could be drawn in accordance with the hypothesis proved which have been established in this research, such as:

1) Competence had a positive affect on employee performance, the greatest influence would be on mental characteristics indicator in dealing with clients.

2) Competence had a positive affect on employee engagement, with the greatest influence on indicators of mental characteristics in facing up with the client.

3) Innovative behaviour had none significant affect on employee performance.

4) Innovative behaviour had a positive affect on employee engagement, with the greatest influence on indicator of creating ideas for emerging problems.

5) Employee engagement had a positive affect on employee performance, with the greatest influence on high morale indicators on problems that arise.

6) Employee engagement as a mediate variable in this research has succeed in influencing the competence on employee performance.

7) Employee engagement as a mediate variable in this research has succeed in influencing the innovative behaviour on employee performance.

\section{Suggestion}

According to the research results, discussion and those conclusions above, several suggestions that could be formulated by the author are:

1) Every company leader is expected to understand and appliance the important thing about being politeness and listening to complaints against clients, which supported by appropriate competency skills:

a) Implementing concepts 10, 20, 70 for training and conducting regular evaluations.

b) Mapping the right skills by optimizing the staffing level and then assessing it every quarter therefore the mapping skills will always updated.

2) Every company leader in dealing with problems which occurs in the workplace through looking for new work methods:

a) Evaluating the percentage of work from the total workload which is the core of an engineer job.

b) Intensive programs which could accelerate the innovative behaviour through idea boxes and regular reviews and apply a recognition system to all employees, especially to those engineers. 
3) Competence and high employee engagement (implementation of concepts 10, 20, 70) could improve the performance and increase the customer satisfaction with the results of service maintenance on each machine so as to increase the value of MME (Machine Mechanical Efficiency).

4) Innovative behaviour is in line with employee engagement, to solve problems which arise in the workplace, the organization need to stimulate the employees through intensive programs that can accelerate their innovative behaviour in carrying out daily tasks. The companies would incubate through the idea box and regularly review and apply a recognition system to all employees, especially to those engineers.

5) Every company leader should always provide the motivation to all engineers:

a) Maintain those momentum on Employee Engagement at all times with a high level of consistency, through a survey program every year and the results are need to communicated to the employees in two ways.

b) As for future researchers, it is that could conduct further research which could dig up more deeper regarding the variables which affect the employee performance. Employee engagement as a mediate variable of competence and innovative behaviour which found along this research did not proved has significant affect, the possibility of other influence variables on employee performance such as leadership, work environment, compensation, work stress, motivation, organizational commitment and organizations culture which could be add up for the next research.

\section{REFERENCES}

Anderson, N., Potočnik, K., \& Zhou, J. (2014). Innovation and creativity in organizations: A state-of-the-science review, prospective commentary, and guiding framework. Journal of Management, 40(5), 1297-1333.

Ataunur, I., \& Ariyanto, E. (2015). Pengaruh Kompetensi dan Pelatihan Terhadap Kinerja Karyawan PT. Adaro Energy Tbk. Telaah Bisnis, Volume 16, Nomor 2.

Claret, A., \& Harry, H. (2014). Pengaruh Kompensasi, Status/Pengakuan, dan Kesempatan Berkembang terhadap Tingkat Emplyee Engagement pada Karyawan Universitas Sanata Dharma. Universitas Atma Jaya: Yogyakarta.

Bedarkar, M \& Pandita, D (2014). A study on the drivers of employee engagement impacting employee performance. Procedia - Social and Behavioral Sciences, 133 (2014), 106 115.

Dayona G., \& Rinawati N. (2016). Pengaruh pelatihan dan pengembangan karir terhadap employee engagementdi pt andalan finance indonesia .Jurnal Indonesia Membangun, 15 (2), 1-23.

Dibrell, C \& Craig, J (2013). Linking the formal strategic planning process, planning flexibility, and innovativeness to firm performance. Journal of Business Research.

Janssen, O. (2000). Job Demands, Perceptions of Effort-Reward Fairness and Innovative Work Behaviour. Journal of Occupational and Organizational Psychology, Vol. 73: 287-302. 
Lasmahadi, A. (2002). Sistem Manajemen SDM Berbasis Kompetensi, http://www.epsikologi.com/epsi/industri_detail.asp?id=131.

Mangkunegara, A.A. (2014). Manajemen Sumber Daya Manusia Perusahaan. Bandung: PT Remaja Rosda Karya.

Mangkunegara, A. A. A. P. (2016). Manajemen Sumber Daya Manusia Perusahaan. Remaja Rosdakarya.

Robbins, S. P., \& Timothy, A. J. (2014). Perilaku Organisasi. Salemba Empat.

Sagung, AA \& Ayu, I (2018). Pengaruh Pemberdayaan, Perilaku Inovatif, dan Motivasi Kerja Terhadap Produktifitas Kerja Karyawan Bumbu Bali Restoran Tanjung Benoa Badung, Bali. Jurnal Inovasi Bisnis dan Manajemen Indonesia.

Shaputra, A.R., \& Hendriani, S. (2015). Pengaruh Kompetensi, Komitmen Dan Pengembangan Karir Terhadap Kinerja Karyawan Pt. Bank Rakyat Indonesia (Persero) Kantor Wilayah Pekanbaru. Jurnal Tepak Manajemen Bisnis Vol VII No 1

Schaufeli, W. B., \& Bakker, A. B. (2004). Utrecht work engagement scale Preliminary Manual Version 1.1. Occupational Health Psychology Unit Utrecht University, December, 160. https://doi.org/10.1037/t01350-000

Shanker, R \& Bhanugopan, R (2017). Organizational climate for innovation and organizational performance: The mediating effect of innovative work behavior. Journal of Vocational Behavior, 100, 67-77. https://doi.org/10.1016/j.jvb.2017.02.004

Spencer, Lyle \& Signe M. Spencer. 1993. Competence at Work, Models For Superior Performance. Canada: John Wiley \& Sons, Inc.

Sujarwo, A \& Wahjono (2017). Pengaruh Motivasi Kerja dan Perilaku Inovatif terhadap Kinerja Karyawan dengan Kepuasan Kerja sebagai Variabel Mediasi. INFOKAM Nomor I Th. XIII/MARET/2017.

Tajeddini, K \& Martin, E (2019). The importance of human-related factors on service innovation and performance. Journal of Hospitality Management, 85, February 2020, 102431. https://doi.org/10.1016/j.ijhm.2019.102431 